\title{
Relationship Between Content of Crude Protein in Rations for Dairy Cows and Milk Yield, Concentration of Urea in Milk and Ammonia Emissions
}

\author{
B. Frank and C. Swensson \\ Department of Agricultural Biosystems and Technology \\ Swedish University of Agricultural Sciences, P.O. Box 59, SE-23053 Alnarp, Sweden
}

\begin{abstract}
During recent decades, efforts have been made in several countries to diminish the negative environmental influence of dairy production. The main focus has been on nitrogen and phosphorus. Modern dairy production in Western Europe is often based on imported feedstuffs, mostly protein-rich feeds. In Sweden at least, it is wished that the use of imported feedstuffs in animal production will decrease due to the risk of contamination with Salmonella and the ban of using GMO crops in Swedish dairy production.

An experiment was carried out to investigate whether a lower content of crude protein in the diet would decrease the ammonia release from cow manure and whether a well-balanced diet using only feedstuffs of Swedish origin would maintain milk production.

Five treatments were arranged in a Latin square design. Two different protein supplements made of ingredients of Swedish origin were each fed at two protein levels, and a fifth imported commercial protein mix was fed at the higher level. The treatments with low protein levels (13.1 to $13.5 \%$ ) had a significantly lower milk yield, kilograms of ECM, but, on the other hand the net profit, milk income minus feed cost was nearly the same in all treatments except diet $\mathrm{C}$, which had lower feed cost but also lower net profit due to lower milk yield. The content of urea in milk was higher with diets high in crude protein (17\%) content. A decreased protein level in the diets did not influence the content of casein or whey protein, but the commercial concentrate showed a tendency to give lower values than the Swedish mixtures. The low protein diets gave significantly lower ammonia release from manure compared with the high protein diets. There were no production differences between the diets of Swedish feeds compared with the imported control. The readily fermentable beet pulp should have helped cows use the higher $\mathrm{N}$ diet more
\end{abstract}

Received November 19, 2001.

Accepted January 29, 2002.

Corresponding author: B. Frank; e-mail: birgit.frank@jbt.slu.se. efficiently and increased the response. This gives the rumen microbes a possibility to match the inflow of protein with carbohydrates. Income over feed costs shows that it is possible to compile diets using products of Swedish origin and still be competitive. On the other hand, this structure may change quickly due to altered world market prices.

(Key words: dairy production, ammonia emission, urea, protein content)

Abbreviation key: AAT = amino acid absorbed in the intestine, $\mathbf{E C M}=$ energy-corrected milk, ECP = endogenous protein, $\mathbf{E P D}$ = rumen degradability, $\mathbf{G M O}=$ genetically modified organisms, $\mathbf{M P}=$ metabolizable protein, $\mathbf{P B V}=$ protein balance in the rumen, $\mathbf{S E K}=$ Swedish crown.

\section{INTRODUCTION}

During recent years, the goal of dairy production has widened to include economic, environmental, and animal welfare concerns (Klint Jensen and Sörensen, 1999). In Europe, considerable efforts have been made to decrease the environmental influence from the whole livestock sector, for example in the Netherlands, Denmark, and Sweden (Kuipers and Mandersloot, 1999; Jakobsson, 1999). Also, in the United States, a process has started to diminish the environmental problems caused by animal production, and this process seems to be accelerating (Nelson, 1999; Meyer et al., 1999). Initially, the focus has been on nitrogen and phosphorus (Chalupa and Ferguson, 1996). In the cowshed, the biggest problem with nitrogen is the emission of ammonia from urine and dung. In Sweden, the livestock sector is responsible for $90 \%$ of the ammonia emissions (50,200 tonne per year) and cattle alone for $64 \%$ or 32,300 tonne per year (Jakobsson, 1999). Ammonia emission from the cattle sector in Denmark is 28,000 tonne per year. In England and Wales, 42,200 tonne per year originate from housing and storage alone (Hutchings et al., 2001; Webb, 2001). In dairy production, most efforts have been concentrated on the development of technical solutions in the stable to decrease ammonia emission, for 
example, floor design or roofs on slurry tanks (Swiestra et al., 2001). However, the greatest inflow of nitrogen to a dairy farm is from four main sources; nitrogen from mineral fertilizer, nitrogen from purchased feedstuffs, nitrogen from fixation by legumes, and nitrogen from the atmosphere (Aarst et al., 1992; Kohn et al., 1997; Cederberg et al., 2000).

The release of ammonia from manure depends on the content of nitrogen. A decrease in the content of nitrogen in manure decreases the emission of ammonia-this relationship is linear (Elzing and Monteny, 1997). The content of nitrogen in manure depends on the feed ration and the feeding strategy of the cow (Chalupa and Ferguson, 1996; Dou et al., 1996; Tomlinson et al., 1996; Paul et al., 1998; Chase, 1999; Godden et al., 2001). James et al. (1999) investigated ammonia volatilization from manure from Holstein heifers, and concluded that increased dietary CP concentration increased nitrogen intake, nitrogen excretion, urea nitrogen excretion, and nitrogen excreted in the urine by the heifers.

During recent decades, the content of protein in the feed ration of dairy cows has been studied more closely (NRC, 2001). Several countries have developed feed evaluation systems, which divide CP into several fractions, depending on the degradation in the rumen (Madsen, 1985). In the beginning of the 1990s, two circumstances in Sweden influenced the protein content in feed rations. Firstly, a new feed evaluation system for dairy cattle was introduced in Sweden and in other Nordic countries-the AAT/PBV system (Madsen, 1985; Magnusson et al., 1990; Madsen et al., 1995). The AAT stands for amino acids adsorbed in the intestine and PBV for protein balance in the rumen. Secondly, import tariffs on protein-rich concentrates were removed in Sweden (Gran et al., 1993), making these feedstuffs cheaper. These two occurrences in combination cooperated to increase both the percentage content and the total amount of protein in the feed rations (Gustafsson, 2000). Dairy production in Sweden, as shown by Cederberg and Mattsson (2000), is dependent on imported feedstuffs. Due to uncertainty about the hygienic quality of imported feedstuffs, there is increasing interest in Sweden in relying on feedstuffs of domestic origin. Imported feedstuffs may be infected with Salmonella, might carry infectants from mad cow disease or be polluted by dioxins. Another problem is the use of GMO (genetically-modified organisms) crops, which are banned as feedstuffs in Swedish dairy production by a voluntary agreement between Swedish dairies and the Swedish feed industry (LRF, 2001). The Swedish environmental policy includes biological diversity as a special goal (The Swedish government, 2000). The largest single imported protein feed in Swedish animal production is soybean meal. Cultivation of soybean often leads to problems with soil erosion and, in the worst cases, to exploitation of tropical rain forest. This is in conflict with the goal of biological diversity (Cederberg, 2001). Therefore, it seems to be of vital interest to decrease the amount of imported feedstuffs with the aim of producing milk mainly by using Swedish feedstuffs.

\section{Aim of Present Study}

The objectives of this study were to test the following hypotheses:

Hypothesis 1: A lower content of CP in the diet should decrease the ammonia release from cow manure.

Hypothesis 2: A well-balanced diet with feedstuffs of Swedish origin should not decrease the milk yield.

\section{MATERIALS AND METHODS}

\section{Feeding}

Five different rations, named A, B, C, D, and E, were compared in the Latin square test. Diets A, B, and D had high protein levels (17\% CP in total DM), and diets $\mathrm{C}$ and $\mathrm{E}$ had a low protein level (13.1 to $13.5 \% \mathrm{CP}$ ). The protein levels were about $1 \%$ lower than initially planned, due to divergent protein content in roughage compared with preliminary analyses. The roughage base consisted of hay, grass silage, and super-pressed beet pulp silage. Concentrates of two types were administered according to actual milk yield. The base concentrate consisted of grain, while the second concentrate consisted of one of three different protein supplements. The five diets are presented in Table 1, and the different concentrates in Table 2 . In ration A, commercial protein supplement was used as a control, while in the other diets two different supplements (SWE 1 and SWE 2) were used, based only on ingredients produced in Sweden.

The protein content in the different rations was regulated partly by the concentrates and partly by the roughage, mostly beet pulp, which was increased when lowering the level of CP.

We do not know the exact composition of the commercial blend, but as a rough estimate, the feed factoryproducing about $90 \%$ of total commercial concentrates in Sweden-stated that the soy products will amount to 30 to $35 \%$, rapeseed products to 20 to $25 \%$, other protein sources such as brewer's grain, peas, and palm kernel meal to 20 to $25 \%$, beet fiber and molasses to 10 to $15 \%$ and others such as fat, vitamins, and minerals 0 to $5 \%$. About $50 \%$ of the supplement have probably been imported. 
Table 1. Feeding regime of roughages and concentrates, kg per day; live weight $650 \mathrm{~kg}$.

\begin{tabular}{|c|c|c|c|c|c|c|c|c|c|c|}
\hline \multirow{3}{*}{$\begin{array}{l}\text { Protein level } \\
\text { Protein conc. }\end{array}$} & & \multicolumn{9}{|c|}{ Feed ration } \\
\hline & & \multirow{2}{*}{\multicolumn{2}{|c|}{$\begin{array}{l}\text { A } \\
\text { High } \\
\text { Control }\end{array}$}} & \multirow{2}{*}{\multicolumn{2}{|c|}{$\begin{array}{l}\text { B } \\
\text { High } \\
\text { SWE 1 }\end{array}$}} & \multirow{2}{*}{\multicolumn{2}{|c|}{$\begin{array}{l}\text { C } \\
\text { Low } \\
\text { SWE } 1\end{array}$}} & \multirow{2}{*}{\multicolumn{2}{|c|}{$\begin{array}{l}\text { D } \\
\text { High } \\
\text { SWE } 2\end{array}$}} & \multirow{2}{*}{$\begin{array}{l}\text { E } \\
\text { Low } \\
\text { SWE } 2 \\
\end{array}$} \\
\hline & & & & & & & & & & \\
\hline \multicolumn{11}{|l|}{ Roughage } \\
\hline Grass hay & & 1 & & 1 & & 1 & & 1 & & 1 \\
\hline Grass silage, $\mathrm{DM}^{1}$ & & 7 & & 7 & & 6.5 & & 7 & & 6.5 \\
\hline Beet pulp silage, $\mathrm{DM}^{2}$ & & 2.5 & & 2.5 & & 5 & & 2.5 & & 5 \\
\hline \multicolumn{11}{|l|}{ Energy-corrected milk } \\
\hline 15 & 0.1 & 2.3 & & 2.5 & & 0.2 & & 2.7 & 0.2 & 0.1 \\
\hline 20 & 1.3 & 3.3 & 0.9 & 3.6 & 1.6 & 0.7 & 0.5 & 4.0 & 1.9 & 0.7 \\
\hline 25 & 2.6 & 4.3 & 1.9 & 4.7 & 3.3 & 1.2 & 1.5 & 5.2 & 3.5 & 1.2 \\
\hline 30 & 3.8 & 5.3 & 3.0 & 5.8 & 5.0 & 1.8 & 2.4 & 6.5 & 5.2 & 1.8 \\
\hline
\end{tabular}

${ }^{1} 75 \%$ grass and $25 \%$ clover, ensiled in bunker silos, $30 \% \mathrm{DM}$.

${ }^{2}$ Super-pressed beet pulp mixed with $5 \%$ molasses and ensiled, 27\% DM.

\section{Animals and Management}

Twenty dairy cows (Swedish Holstein) from the experimental dairy herd were used in the experiment. When half of the cows had calved, they were randomly grouped into two blocks ( 1 and 2 ) and the feeding experiment could start, with cows in their first month of lactation. The same procedure was repeated 1 mo later with the other 10 cows in blocks 3 and 4 (Table 3 ). The cows were in their second or later lactation. They were kept in tie stalls and milked twice daily. The barn at the experimental farm was equipped with mobile feed carriers for individual feeding of all feedstuffs. Roughages were fed twice a day and concentrate mixtures four times daily. Feed refusals were weighed every morning.

As mentioned earlier, five different treatments were tested. The design of the experiment is given in Table 3. Each period extended over $6 \mathrm{wk}$; the first $2 \mathrm{wk}$ were preexperimental to get the cow adapted to the new feeding regimen. Total daily amounts of feces and urine were collected together from individual cows in blocks 1 and 3, during $4 \mathrm{~d}$ in the last week of each period.

\section{Registrations and Analyses}

Feeds. Samples of silages were collected every day and frozen for later analysis of pooled 2-wk samples. Samples of concentrate ingredients and blends were taken on each mixing occasion. Samples were pooled for $4 \mathrm{wk}$. Chemical analyses were made on pooled samples, and nutrition values were calculated according to standard methods (Spörndly, 1995). Analyses and feed values are presented in Table 4.

Milk. Individual milk recording with milk sampling was done $2 \mathrm{~d}$ weekly. Pooled milk samples were analyzed every week at a commercial dairy laboratory. The

Table 2. Recipe of concentrate mixtures, percent of mixture.

\begin{tabular}{llcc}
\hline & & Mixture & \\
\cline { 2 - 4 } & Base & SWE 1 & SWE 2 \\
\hline Barley & 45 & & \\
Oats & 25 & & \\
Wheat & 30 & 22.5 & 22.5 \\
Peas & & 15.0 & 20.0 \\
Rapeseed meal, heat-treated & & 35.0 & 15.0 \\
Rapeseed expeller, heat treated & & 12.5 & 15.0 \\
Dried brewer's grain & & 15.0 & 15.0 \\
Dried beet pulp fiber & 1.30 & & 12.5 \\
Linseed cake & & 1.87 & 1.99 \\
Price, Swedish crowns, SEK/kg ${ }^{1}$ & & & \\
\hline
\end{tabular}

${ }^{1}$ Calculated with prices as per September, 2001. 
Table 3. Block design. A, B, C, D, E refer to different diets.

\begin{tabular}{|c|c|c|c|c|c|c|c|c|c|c|}
\hline Block & & & $1^{1}$ & & & & & 2 & & \\
\hline Period 1 & A & B & $\mathrm{C}$ & D & $\mathrm{E}$ & $\mathrm{A}$ & $\mathrm{C}$ & B & D & $\mathrm{E}$ \\
\hline Period 2 & B & $\mathrm{C}$ & $\mathrm{D}$ & $\mathrm{E}$ & A & $\mathrm{C}$ & $\mathrm{E}$ & D & A & B \\
\hline Period 3 & $\mathrm{C}$ & D & $\mathrm{E}$ & A & B & B & D & A & $\mathrm{E}$ & $\mathrm{C}$ \\
\hline Period 4 & D & $\mathrm{E}$ & A & B & $\mathrm{C}$ & $\mathrm{E}$ & A & $\mathrm{C}$ & B & $\mathrm{D}$ \\
\hline Period 5 & $\mathrm{E}$ & A & B & $\mathrm{C}$ & $\mathrm{D}$ & $\mathrm{D}$ & B & $\mathrm{E}$ & $\mathrm{C}$ & $\mathrm{A}$ \\
\hline Block & & & $3^{1}$ & & & & & 4 & & \\
\hline Period 1 & A & $\mathrm{C}$ & $\mathrm{E}$ & D & B & $\mathrm{C}$ & B & $\mathrm{E}$ & D & A \\
\hline Period 2 & $\mathrm{E}$ & A & $\mathrm{C}$ & B & D & A & $\mathrm{C}$ & B & $\mathrm{E}$ & D \\
\hline Period 3 & D & B & A & $\mathrm{C}$ & $\mathrm{E}$ & $\mathrm{D}$ & A & $\mathrm{C}$ & B & $\mathrm{E}$ \\
\hline Period 4 & B & $\mathrm{E}$ & $\mathrm{D}$ & A & $\mathrm{C}$ & $\mathrm{E}$ & D & A & $\mathrm{C}$ & B \\
\hline Period 5 & $\mathrm{C}$ & $\mathrm{D}$ & B & $\mathrm{E}$ & A & B & $\mathrm{E}$ & $\mathrm{D}$ & A & $\mathrm{C}$ \\
\hline
\end{tabular}

${ }^{1}$ Manure was collected.

contents of true protein, fat, lactose, urea, and SCC in milk were analyzed by the infrared technical instrument Foss Combi (Foss Electric AS, Denmark). The reference methods were as follows for fat: Röse Gottlieb, IDF standard ID, 1996; for protein: Kjeldahl IDF standard 20B, 1993 part 3; and for SCC, direct count in microscope, IDF standard 148A, 1995. Lactose and urea estimations were based on national and international ring tests.

Live weight. The cows were weighed in the beginning of the trial and at the end of each period. The body condition was scored at the beginning of the trial and after the whole trial was finished.

Manure. During four consecutive days in the last week of each period, plastic bins were placed in the manure channel behind each cow in blocks 1 and 3 for total collection of individual feces and urine for $24 \mathrm{~h}$ at a time. The collected amount was thoroughly mixed, and a sample was frozen for chemical analyses. During these days, the cows were separated by empty tie stalls in order to avoid a mixture of manures.

Frozen samples of manure were analyzed at a commercial agricultural laboratory. The DM was analyzed (Ref. SS 028113) together with the contents of total N (Ref. SS 028101:1-92 mod) and $\mathrm{NH}_{4}-\mathrm{N}$ (Ref. KLK 71950 mod). Total $\mathrm{N}$ and $\mathrm{NH}_{4}-\mathrm{N}$ were estimated in wet material to avoid losses of ammonia.

About one third of the fresh manure was put in a plastic bin, and the ammonia release was estimated with a ventilated chamber, constructed at the department. This analytical technique to determine ammonia release from feces and urine has been described by Andersson (1994). Ammonia concentrations in the chamber air were measured with reagent tubes (Kitagawa). The ventilation rate through the chamber was determined by measuring the pressure difference over an orifice plate. To eliminate errors caused by variations in ventilation rate, all determinations were made at a

Table 4. Chemical analyses and calculated nutrient contents in feeds.

\begin{tabular}{|c|c|c|c|c|c|c|c|c|c|c|c|c|c|c|}
\hline \multirow[b]{2}{*}{ Number of analyses } & \multicolumn{2}{|c|}{ Hay } & \multicolumn{2}{|c|}{$\begin{array}{l}\text { Grass } \\
\text { silage }\end{array}$} & \multicolumn{2}{|c|}{$\begin{array}{l}\text { Beet pulp } \\
\text { silage }\end{array}$} & \multicolumn{2}{|c|}{ Base } & \multicolumn{2}{|c|}{ SWE 1} & \multicolumn{2}{|c|}{ SWE 2} & \multicolumn{2}{|c|}{$\begin{array}{l}\text { Commercial } \\
\text { blend }^{1}\end{array}$} \\
\hline & $\begin{array}{l}\text { LSM } \\
8 \\
\end{array}$ & SD & $\begin{array}{l}\text { LSM } \\
9 \\
\end{array}$ & SD & $\begin{array}{l}\text { LSM } \\
8 \\
\end{array}$ & SD & $\begin{array}{l}\text { LSM } \\
8 \\
\end{array}$ & SD & $\begin{array}{l}\text { LSM } \\
7\end{array}$ & SD & $\begin{array}{l}\text { LSM } \\
7\end{array}$ & SD & $\begin{array}{l}\text { LSM } \\
7\end{array}$ & $\mathrm{SD}$ \\
\hline $\mathrm{DM}, \%$ & 84.8 & 1.2 & 30.1 & 2.2 & 26.4 & 0.8 & 87.2 & 0.0 & 89.2 & 0.00 & 89.1 & 0.00 & 88.5 & 1.1 \\
\hline \multicolumn{15}{|l|}{ In $\%$ of $\mathrm{DM}$} \\
\hline $\mathrm{CP}$ & 13.0 & 1.4 & 16.3 & 2.0 & 9.7 & 2.6 & 11.0 & 3.2 & 27.8 & 0.4 & 27.3 & 0.04 & 27.8 & 0.6 \\
\hline NDF & 56.3 & 3.0 & 45.8 & 5.9 & 43.7 & 1.4 & 19.6 & 4.8 & 28.2 & 1.1 & 28.6 & 1.8 & 31.5 & \\
\hline Starch & & & & & & & 59.7 & 4.6 & 12.2 & 1.0 & 12.2 & 1.0 & 8.1 & 1.5 \\
\hline \multicolumn{15}{|l|}{ Per kg of feed } \\
\hline MJ metabolizable energy & 8.82 & 0.30 & 3.28 & 0.24 & 3.41 & 0.06 & 11.79 & 0.12 & 12.32 & 0.14 & 12.35 & 0.13 & 12.0 & \\
\hline $\mathrm{AAT}^{2} \mathrm{~g}$ & 61 & 0.4 & 22 & 0.9 & 27 & 2.0 & 73 & 3.4 & 123 & 10.3 & 115 & 8.6 & 140 & \\
\hline $\mathrm{PBV}^{3} \mathrm{~g}$ & 6 & 1.1 & 12 & 5.1 & -19 & 2.8 & -22 & 6.3 & 67 & 27.3 & 70 & 13.8 & 30 & \\
\hline $\mathrm{CP}, \mathrm{g}$ & 110 & 12.1 & 49 & 6.1 & 26 & 0.9 & 97 & 2.8 & 248 & 4.0 & 243 & 8.7 & 246 & \\
\hline
\end{tabular}

${ }^{1}$ Partly from chemical analyses, partly guaranteed values.

${ }^{2} \mathrm{AAT}=$ Amino acid absorbed in the intestine.

${ }^{3} \mathrm{PBV}=$ Protein balance in the rumen. 
Table 5. Total amount of consumed nutrients in the different treatments.

\begin{tabular}{|c|c|c|c|c|c|}
\hline \multirow[b]{2}{*}{$\begin{array}{l}\text { Level of protein } \\
\text { CP\% }\end{array}$} & \multirow{2}{*}{$\begin{array}{l}\text { Control } \\
\text { A } \\
\text { High } \\
17\end{array}$} & \multicolumn{2}{|c|}{ Concentrate SWE 1} & \multicolumn{2}{|c|}{ Concentrate SWE 2} \\
\hline & & $\begin{array}{l}\text { B } \\
\text { High } \\
16.6\end{array}$ & $\begin{array}{l}\text { C } \\
\text { Low } \\
13.1\end{array}$ & $\begin{array}{l}\text { D } \\
\text { High } \\
17\end{array}$ & $\begin{array}{l}\mathrm{E} \\
\text { Low } \\
13.5\end{array}$ \\
\hline DM, kg & 20.3 & 20.4 & 19.9 & 20.3 & 19.1 \\
\hline $\begin{array}{l}\text { CP, g } \\
\text { Fat, g } \\
\text { NDF, g } \\
\text { Starch, g } \\
\text { AAT, }{ }^{1} \text { g } \\
\text { PBV, }{ }^{g} \\
\text { MJ metabolizable energy }\end{array}$ & $\begin{array}{r}3451 \\
893 \\
7252 \\
3035 \\
2040 \\
133 \\
244\end{array}$ & $\begin{array}{r}3387 \\
855 \\
6946 \\
3000 \\
1906 \\
366 \\
239\end{array}$ & $\begin{array}{r}2615 \\
587 \\
6744 \\
3990 \\
1692 \\
-173 \\
234\end{array}$ & $\begin{array}{r}3448 \\
911 \\
6941 \\
2654 \\
1861 \\
449 \\
238\end{array}$ & $\begin{array}{r}2572 \\
602 \\
6475 \\
3808 \\
1633 \\
-122 \\
225\end{array}$ \\
\hline
\end{tabular}

${ }^{1} \mathrm{AAT}=$ Amino acid absorbed in the intestine.

${ }^{2} \mathrm{PBV}=$ Protein balance in the rumen .

ventilation rate of $100 \mathrm{~m}^{3} / \mathrm{m}^{2} \mathrm{~h}$ and at a room temperature close to $16^{\circ} \mathrm{C}$. The intention with the applied method for estimation of ammonia release is mainly to express the relative differences between feed rations, not to give the exact values of ammonia release per cow and day.

\section{Statistical Analysis}

The experimental design was Latin square. The analyses were made using the SAS statistical package (SAS, 1986). As values of somatic cells are not in normal distribution, they were transformed in logarithmic scale before the statistical analysis.

$$
\begin{aligned}
Y_{i j k l m}= & \mu+a_{i}+\beta_{j}+\gamma_{k}+\delta_{l}\left(a_{i}\right)_{i}+(\beta \gamma)_{j k}+e_{i j k l m} \\
Y_{i j k l m}= & \text { Milk: yield (kg/day), fat \%, protein \%, lac- } \\
& \text { tose } \%, \text { casein } \%, \text { whey protein } \% \text { NPN } \%, \\
& \text { urea }(\text { mmol } / 1), \text { casein, NPN, soluble nitro- } \\
& \text { gen, total nitrogen, whey protein; } \\
\text { Manure }= & \text { Manure: DM, ammonia kilogram per } \\
& \text { tonne manure, total amount of nitrogen } \\
& \text { per tonne manure, soluble nitrogen per } \\
& \text { tonne manure, NPN, organic nitrogen in } \\
& \text { manure; } \\
a_{i}= & \text { block; } \\
\beta_{j}= & \text { period; } \\
\gamma_{k}= & \text { treatment (diet }) ; \\
\delta_{l}\left(a_{i}\right)= & \text { cow within block; } \\
(\beta \gamma)_{j k}= & \text { interplay between period and treatment; } \\
& \text { and } \\
e_{i j k l m}= & \text { random effect. }
\end{aligned}
$$

\section{RESULTS}

\section{Feed Consumption}

The average daily feed consumption is presented in Table 5. The diets fulfilled the need of metabolizable energy and CP but was not optimized due to AAT and PBV.

\section{Milk}

No significant differences in yield of milk or ECM (energy-corrected milk with $4 \%$ fat and $3.4 \%$ protein) were observed between the different protein supplements at high protein level (A, B, and D). The low protein levels ( $\mathrm{C}$ and $\mathrm{E}$ ) resulted in lower yields, especially in the amount of milk (Table 6). The content of milk protein was significantly lower in the control diet A, compared with all other diets. Milk fat was not significantly affected. However, slightly higher concentrations of different milk constituents, when low protein concentrations were fed, resulted in only small differences between diets in daily yields of milk fat and milk protein. The content of urea was significantly higher $(P<0.0001)$ in treatments with high CP level in the diet.

The results of analyses of different nitrogen fractions in morning milk sampled in blocks 1 and 3 during the weeks of manure collection are presented in Table 7 . Total $\mathrm{N}$ was significantly lower for $\operatorname{diet} \mathrm{A}$. The NPN was significantly higher at high protein level in the diet. The contents of casein and whey were influenced by protein level in the diet. Thus, the high level, especially with the commercial concentrate, decreased both casein and whey content.

\section{Nitrogen Efficiency}

In Figure 1, the nitrogen efficiency is presented, calculated as $\mathrm{N}$ from true milk protein in percentage of 
Table 6. Average daily milk yield at different diets.

\begin{tabular}{|c|c|c|c|c|c|c|c|}
\hline & & $\begin{array}{l}\text { Control } \\
\text { A } \\
\text { High }\end{array}$ & \multicolumn{2}{|c|}{ Concentrate SWE 1} & \multicolumn{2}{|c|}{ Concentrate SWE 2} & $\begin{array}{l}P \\
\text { for diets }\end{array}$ \\
\hline Milk fat, $\%$ & $\begin{array}{l}\text { LSM } \\
\text { SD }\end{array}$ & $\begin{array}{l}3.79 \\
0.49\end{array}$ & $\begin{array}{l}3.83 \\
0.46\end{array}$ & $\begin{array}{l}3.96 \\
0.38\end{array}$ & $\begin{array}{l}3.84 \\
0.41\end{array}$ & $\begin{array}{l}3.84 \\
0.59\end{array}$ & $\begin{array}{l}0.43 \\
\mathrm{NS}\end{array}$ \\
\hline Milk lactose, $\%$ & $\begin{array}{l}\text { LSM } \\
\text { SD }\end{array}$ & $\begin{array}{l}4.94 \\
0.14\end{array}$ & $\begin{array}{l}4.95 \\
0.13\end{array}$ & $\begin{array}{l}4.96 \\
0.13\end{array}$ & $\begin{array}{l}4.94 \\
0.15\end{array}$ & $\begin{array}{l}4.97 \\
0.11\end{array}$ & $\begin{array}{l}0.7 \\
\mathrm{NS}\end{array}$ \\
\hline Energy-corrected milk, kg & $\begin{array}{l}\text { LSM } \\
\text { SD }\end{array}$ & $\begin{array}{c}35.1^{\mathrm{a}} \\
6.3\end{array}$ & $\begin{array}{c}34.6^{\mathrm{a}} \\
4.3\end{array}$ & $\begin{array}{c}32.4^{\mathrm{b}} \\
4.6\end{array}$ & $\begin{array}{c}34.9^{\mathrm{a}} \\
6.1\end{array}$ & $\begin{array}{r}33.0^{\mathrm{b}} \\
5.22\end{array}$ & $\begin{array}{l}0.005 \\
* *\end{array}$ \\
\hline Milk fat, $\mathrm{g}$ & $\begin{array}{l}\text { LSM } \\
\text { SD }\end{array}$ & $\begin{array}{r}1355 \\
278\end{array}$ & $\begin{array}{r}1329 \\
154\end{array}$ & $\begin{array}{r}1273 \\
193\end{array}$ & $\begin{array}{r}1348 \\
250\end{array}$ & $\begin{array}{r}1263 \\
222\end{array}$ & $\begin{array}{l}0.07 \\
\text { NS }\end{array}$ \\
\hline $\mathrm{SCC}, \log 10,1000$ per $\mathrm{ml}$ & $\begin{array}{l}\text { LSM } \\
\text { SD }\end{array}$ & $\begin{array}{l}2.125 \\
0.4053\end{array}$ & $\begin{array}{l}2.0899 \\
0.5021\end{array}$ & $\begin{array}{l}1.9858 \\
0.4217\end{array}$ & $\begin{array}{l}2.0144 \\
0.4133\end{array}$ & $\begin{array}{l}2.0414 \\
0.3804\end{array}$ & $\begin{array}{l}0.8409 \\
\mathrm{NS}\end{array}$ \\
\hline
\end{tabular}

${ }^{\mathrm{a}, \mathrm{b}, \mathrm{c}, \mathrm{d}}$ Values within a row without common letter differ significantly $(P<0.05)$.

**Significance level; $P<0.01$.

****Significance level; $P<0.001$.

total consumed $\mathrm{N}$, without consideration to changes in BW or score. Extremely high efficiencies around $42 \%$ were observed with low protein diets. The efficiency was also rather high, around $34 \%$, with the high level diets. According to Aarts et al. (1992), in a cite of van Vuuren and Mejs (1987), maximum $43 \%$ of ingested N can be transferred into milk and body yield. Aarts et al. (1992) are of the opinion that the nitrogen efficiency in practice will be 15 to $25 \%$. In our Swedish experimen- tal herd, the $\mathrm{N}$ efficiency has been around 25 to $32 \%$, when feeding after standard recommendations ( $19 \%$ $\mathrm{CP})$.

\section{Manure}

Daily amounts of fresh manure or manure DM percent did not differ significantly between diets. There were significant differences in both total-N and ammo-

Table 7. Average milk quality expressed as content of milk nitrogen fractions in morning milk. Blocks 1 and 3.

\begin{tabular}{|c|c|c|c|c|c|c|c|}
\hline \multirow[b]{2}{*}{ Item } & & \multirow{2}{*}{$\begin{array}{l}\text { Control } \\
\text { A } \\
\text { High }\end{array}$} & \multicolumn{2}{|c|}{ Concentrate SWE 1} & \multicolumn{2}{|c|}{ Concentrate SWE 2} & \multirow[b]{2}{*}{$\begin{array}{l}P \\
\text { for diets }\end{array}$} \\
\hline & & & $\begin{array}{l}\text { B } \\
\text { High }\end{array}$ & $\begin{array}{l}\mathrm{C} \\
\text { Low }\end{array}$ & $\begin{array}{l}\text { D } \\
\text { High }\end{array}$ & $\begin{array}{l}\mathrm{E} \\
\text { Low }\end{array}$ & \\
\hline Total N, \% & $\begin{array}{l}\text { LSM } \\
\text { SD }\end{array}$ & $\begin{array}{l}0.482^{\mathrm{a}} \\
0.033\end{array}$ & $\begin{array}{l}0.498^{\mathrm{ab}} \\
0.034\end{array}$ & $\begin{array}{l}0.504^{\mathrm{b}} \\
0.034\end{array}$ & $\begin{array}{l}0.507^{\mathrm{b}} \\
0.030\end{array}$ & $\begin{array}{l}0.511^{\mathrm{b}} \\
0.047\end{array}$ & $\underset{*}{0.0258}$ \\
\hline Soluble N, \% & $\begin{array}{l}\text { LSM } \\
\text { SD }\end{array}$ & $\begin{array}{l}0.109 \\
0.009\end{array}$ & $\begin{array}{l}0.112 \\
0.012\end{array}$ & $\begin{array}{l}0.1108 \\
0.013\end{array}$ & $\begin{array}{l}0.117 \\
0.010\end{array}$ & $\begin{array}{l}0.113 \\
0.015\end{array}$ & $\begin{array}{l}0.0837 \\
\mathrm{NS}\end{array}$ \\
\hline NPN, \% & $\begin{array}{l}\text { LSM } \\
\text { SD }\end{array}$ & $\begin{array}{l}0.027^{\mathrm{a}} \\
0.003\end{array}$ & $\begin{array}{l}0.028^{\mathrm{a}} \\
0.003\end{array}$ & $\begin{array}{l}0.021^{b} \\
0.002\end{array}$ & $\begin{array}{l}0.030^{c} \\
0.003\end{array}$ & $\begin{array}{l}0.023^{b} \\
0.002\end{array}$ & $\begin{array}{l}<0.0001 \\
* * *\end{array}$ \\
\hline Casein, \% & $\begin{array}{l}\text { LSM } \\
\text { SD }\end{array}$ & $\begin{array}{l}2.38^{\mathrm{a}} \\
0.22\end{array}$ & $\begin{array}{l}2.47^{\mathrm{ab}} \\
0.20\end{array}$ & $\begin{array}{l}2.53^{b} \\
0.11\end{array}$ & $\begin{array}{l}2.49^{\mathrm{b}} \\
0.22\end{array}$ & $\begin{array}{l}2.54^{\mathrm{b}} \\
0.26\end{array}$ & $*^{0.0153}$ \\
\hline Whey protein, \% & $\begin{array}{l}\text { LSM } \\
\text { SD }\end{array}$ & $\begin{array}{l}0.522^{\mathrm{a}} \\
0.055\end{array}$ & $\begin{array}{l}0.535^{\mathrm{a}} \\
0.080\end{array}$ & $\begin{array}{l}0.550^{\mathrm{ab}} \\
0.085\end{array}$ & $\begin{array}{l}0.555^{\mathrm{ab}} \\
0.049\end{array}$ & $\begin{array}{l}0.578^{b} \\
0.091\end{array}$ & $\begin{array}{l}0.1241 \\
\mathrm{NS}\end{array}$ \\
\hline
\end{tabular}

a,b,c Values within a row without common letter differ significantly $(P<0.05)$.

$* P<0.05$.

$* * * P<0.001$. 


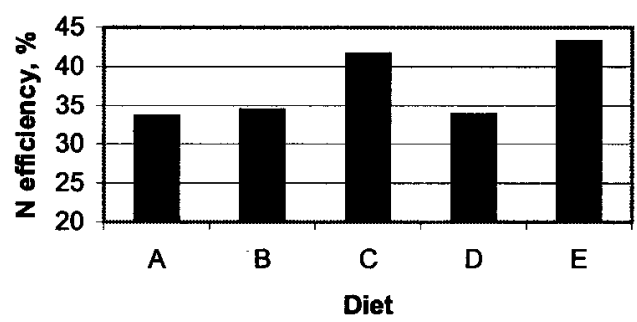

Figure 1. Nitrogen efficiency with different diets.

nium-N in wet manure depending on the content of $\mathrm{CP}$ in the diet (Table 8). Especially, diet D showed high levels of nitrogen in manure. The concentrate SWE 2 included linseed cake in contrast to the other concentrate mixtures. The protein level had little influence on organically bound $\mathrm{N}$.

Comparing the production of manure and nitrogen in manure on a yearly basis, excluding the pasture period, clearly demonstrates a lower production of nitrogen with a lower protein content in feed. Especially, the production of ammonia decreases in treatments $\mathrm{C}$ and E (Table 9).

\section{Ammonia Release}

The results from the estimation of ammonia release from fresh manure are presented in Table 10. The low protein diets $\mathrm{C}$ and $\mathrm{E}$ gave significantly lower ammonia release compared with the high protein $\operatorname{diets}(P<$ 0.0001). Even here, a slightly higher level of ammonia ppm was observed for the linseed concentrate, especially between diets $\mathrm{E}$ and $\mathrm{C}(P=0.18)$.

\section{Economic Comparison}

The average daily consumption of the different concentrates is presented in Table 11 . The prices of concentrate feeds are given in Table 2. The concentrate in $\operatorname{diet} \mathrm{A}$, a commercial concentrate from the local feed supplier, costs 2.38 SEK (Swedish crown) per kilogram. The cost of the grain mixture is 1.30 SEK per kilogram. In Figure 2, a relative comparison is made of income over feed costs. Diet $\mathrm{C}$ had a lower feed cost per kilogram of milk, but also lower milk yield, which influenced on net profit. The other treatments have nearly same net profit (Figure 2).

It is always difficult to make an economic comparison due to the shifting prices on the world market. From Table 11 it can be concluded that a change in the grain price will reflect in the competitiveness of $\mathrm{C}$ and $\mathrm{E}$, due to their high consumption of grain. Figure 2 shows that, at current prices, the diets with Swedish feed ingredients are competitive.

\section{DISCUSSION}

According to Tamminga (1992) the nitrogen content in dairy diets should not exceed $30 \mathrm{~g}$ of $\mathrm{N} / \mathrm{kg}$ of DM. This corresponds to a content of CP of $187 \mathrm{~g} / \mathrm{kg}$ of DM or $18.7 \% \mathrm{CP}$. Wu and Satter (2000) investigating highyielding cows treated with bST, recommended highyielding cows $(\sim 11,000 \mathrm{~kg} / 308 \mathrm{~d})$, a minimum of $17.5 \%$ CP including 35 to 37\% RUP. Crude protein for bSTtreated cows ought to be reduced to $16 \%$ after midlactation. The feeding frequency has influence on the ideal CP content in the diet. St-Pierre and Thraen (1999) consider that, with TMR, it is possible to decrease the

Table 8. Daily amounts of manure per cow and the contents of $\mathrm{DM}, \mathrm{N}$ and $\mathrm{NH}_{4}-\mathrm{N}$ in manure.

\begin{tabular}{|c|c|c|c|c|c|c|c|}
\hline \multirow[b]{2}{*}{ Item } & & \multirow{2}{*}{$\begin{array}{l}\text { Control } \\
\text { A } \\
\text { High }\end{array}$} & \multicolumn{2}{|c|}{ Concentrate SWE 1} & \multicolumn{2}{|c|}{ Concentrate SWE 2} & \multirow[b]{2}{*}{$\begin{array}{l}P \\
\text { for diets }\end{array}$} \\
\hline & & & $\begin{array}{l}\text { B } \\
\text { High }\end{array}$ & $\begin{array}{l}\mathrm{C} \\
\text { Low }\end{array}$ & $\begin{array}{l}\text { D } \\
\text { High }\end{array}$ & $\begin{array}{l}\mathrm{E} \\
\text { Low }\end{array}$ & \\
\hline Fresh manure, $\mathrm{kg}$ & $\begin{array}{l}\text { LSM } \\
\text { SD }\end{array}$ & $\begin{array}{r}47.4 \\
5.0\end{array}$ & $\begin{array}{r}47.2 \\
5.9\end{array}$ & $\begin{array}{r}44.5 \\
4.2\end{array}$ & $\begin{array}{r}47.4 \\
6.5\end{array}$ & $\begin{array}{r}44.1 \\
8.1\end{array}$ & $\begin{array}{l}0.3512 \\
\mathrm{NS}\end{array}$ \\
\hline $\mathrm{DM}, \%$ & $\begin{array}{l}\text { LSM } \\
\text { SD }\end{array}$ & $\begin{array}{r}14.5 \\
1.5\end{array}$ & $\begin{array}{r}14.4 \\
1.5\end{array}$ & $\begin{array}{r}14.1 \\
1.3\end{array}$ & $\begin{array}{r}14.4 \\
1.9\end{array}$ & $\begin{array}{r}14.6 \\
2.2\end{array}$ & $\begin{array}{l}0.9388 \\
\mathrm{NS}\end{array}$ \\
\hline Manure DM, kg & $\begin{array}{l}\text { LSM } \\
\text { SD }\end{array}$ & $\begin{array}{l}6.8 \\
0.4\end{array}$ & $\begin{array}{l}6.7 \\
0.8\end{array}$ & $\begin{array}{l}6.3 \\
0.6\end{array}$ & $\begin{array}{l}6.7 \\
0.6\end{array}$ & $\begin{array}{l}6.3 \\
0.7\end{array}$ & $\begin{array}{l}0.3277 \\
\mathrm{NS}\end{array}$ \\
\hline Total-N, kg/tonne & $\begin{array}{l}\text { LSM } \\
\text { SD }\end{array}$ & $\begin{array}{l}6.05^{\mathrm{a}} \\
0.84\end{array}$ & $\begin{array}{l}6.10^{\mathrm{a}} \\
0.67\end{array}$ & $\begin{array}{l}4.89^{b} \\
0.55\end{array}$ & $\begin{array}{l}6.70^{\mathrm{c}} \\
0.73\end{array}$ & $\begin{array}{l}5.11^{\mathrm{b}} \\
0.92\end{array}$ & $\begin{array}{l}<0.0001 \\
* * *\end{array}$ \\
\hline NH4-N, kg/tonne & $\begin{array}{l}\text { LSM } \\
\text { SD }\end{array}$ & $\begin{array}{l}2.06^{\mathrm{a}} \\
0.48\end{array}$ & $\begin{array}{l}2.06^{\mathrm{a}} \\
0.41\end{array}$ & $\begin{array}{l}0.92^{\mathrm{b}} \\
0.41\end{array}$ & $\begin{array}{l}2.44^{\mathrm{c}} \\
0.44\end{array}$ & $\begin{array}{l}0.93^{\mathrm{b}} \\
0.35\end{array}$ & $\begin{array}{l}<0.0001 \\
* * *\end{array}$ \\
\hline Organic $\mathrm{N}, \mathrm{kg} /$ tonne $^{1}$ & $\begin{array}{l}\text { LSM } \\
\text { SD }\end{array}$ & $\begin{array}{l}3.99 \\
0.43\end{array}$ & $\begin{array}{l}4.04 \\
0.36\end{array}$ & $\begin{array}{l}3.94 \\
0.35\end{array}$ & $\begin{array}{l}4.26 \\
0.49\end{array}$ & $\begin{array}{l}4.18 \\
0.75\end{array}$ & $\begin{array}{l}0.1521 \\
\mathrm{NS}\end{array}$ \\
\hline
\end{tabular}

${ }^{\mathrm{a}, \mathrm{b}, \mathrm{c}}$ Values within row without common letter are significantly different $(P<0.05)$.

${ }^{1}$ Values calculated as difference between total- $\mathrm{N}$ and $\mathrm{NH}_{4}-\mathrm{N}$.

$* * * P<0.001$ 
Table 9. Influence of treatments on the total production of $\mathrm{N}$ in manure ( $300 \mathrm{~d}, \mathrm{~kg} / \mathrm{cow})$.

\begin{tabular}{lllll}
\hline Treatment & Manure, kg/d & $\begin{array}{l}\text { Production of } \\
\text { total N, kg }\end{array}$ & $\begin{array}{l}\text { Production of } \\
\text { ammonia, kg }\end{array}$ & $\begin{array}{l}\text { Production of } \\
\text { organic N, kg }\end{array}$ \\
\hline A & 47.4 & 123 & 42 & 81 \\
B & 47.2 & 123 & 47 & 82 \\
C & 44.5 & 91 & 17 & 74 \\
D & 47.4 & 135 & 49 & 86 \\
E & 44.1 & 97 & 18 & 79 \\
\hline
\end{tabular}

average $\mathrm{CP}$ content from $17.7 \% \mathrm{CP}$ in single TMR to $17.3 \% \mathrm{CP}$ by splitting the herd in three groups. In the latest issue of NRC (2001), they conclude, based on several protein feeding trials, that increased content of $\mathrm{CP}$ in the diet gave increased milk production, but above $19 \%$ the increase was not large and the relationship was not strong. NRC (2001) divides the CP into several fractions; metabolizable protein (MP), instead of absorbed protein, RDP, and RUP. RUP is not a constant fraction; it varies depending on the outflow rate from rumen or the rate of degradation in the rumen. MP consists of microbe protein + RUP + endogenous protein (ECP) (Gustafsson, 2001). The MP is close to AAT in the Nordic protein evaluation system (Madsen, 1985).

In our investigation, CP varied between 13.1 and $17 \%$ of DM in the diets. The very low protein levels, especially in diet C, resulted in lower milk yield for diets $\mathrm{C}$ and $\mathrm{E}$ (Table 6). One explanation of this may be that these treatments had an overall lower feed consumption. The control diet A gave a significantly lower protein content in the milk compared with all other diets. The amount of NPN and the amount of urea were significantly lower in the treatments with lower protein content in the diet (Tables 6 and 7). Furthermore, a higher protein content in the feed ration led to lowered casein content and a tendency to decreased whey protein (Table 7). The Swedish AAT recommendations were fulfilled or exceeded in treatments A, B, and D (45 to $40 \mathrm{~g} \mathrm{AAT} / \mathrm{kg}$ of ECM), but only $37 \mathrm{~g}$ of AAT in diets $\mathrm{C}$ and $\mathrm{E}$. On the other hand, the higher value of $45 \mathrm{~g}$ of AAT in diet A is in accordance with applied practical feeding in Sweden (Lidström, 2001). The PBV value was below recommendations in treatments $\mathrm{C}$ and
$\mathrm{E}$, but without seriously decreasing the milk yield (Table 6). An explanation of this is, as pointed out by NRC (2001), that the mixture between protein or, more accurately, protein fractions and the different types of carbohydrates is more important than the total amount of CP in the diet. The linseed cake might explain the higher release of ammonia and nitrogen in manure in diet $\mathrm{D}$. The cake was cold-pressed and not heated, like the rapeseed meal, which might have resulted in a faster degradability in the rumen.

At the same protein level, the diets with Swedish origins functioned as well as the control diet and no significant differences in milk production were observed between diets $\mathrm{A}, \mathrm{B}$, and $\mathrm{D}$. In contrast, the very low protein levels in diets $\mathrm{C}$ and $\mathrm{E}$ resulted in decreased milk yield. In an earlier feeding experiment (Frank and Nilsson, 1998), the comparison of diets with 19,16 , and $14.5 \% \mathrm{CP}$ did not result in influences on milk production. Other influences on milk protein content and fractions agreed with the results in the present study. The very high nitrogen efficiency (Figure 2 ) in this experiment is probably connected with the beet fiber in the diets, which gives the rumen microbes a possibility to match the inflow of protein with easily digestible carbohydrates of other types than starch. The carbohydrates in the super-pressed beet pulp are to 50\% composed of pectin and hemicelluloses, which are digestible in the rumen to nearly $100 \%$. The cow consumes the beet pulp silage during a longer time compared with concentrates. This ought to result in a more even fermentation in the rumen with improved feed utilization. Furthermore, the protein in beet pulp consists to $97 \%$ of true protein as amides and NPN are released during the sugar extraction process (Kelly, 1983). The rumen de-

Table 10. Ammonia release from fresh manure with different diets, ppm in ventilation chamber outlet air.

\begin{tabular}{|c|c|c|c|c|c|c|c|}
\hline \multirow[b]{3}{*}{ Level of CP } & & \multirow{3}{*}{$\begin{array}{l}\text { Control } \\
\text { A } \\
\text { High }\end{array}$} & \multicolumn{2}{|c|}{ Concentrate SWE 1} & \multicolumn{2}{|c|}{ Concentrate SWE 2} & \multirow[b]{3}{*}{$P$} \\
\hline & & & $\mathrm{B}$ & $\mathrm{C}$ & $\mathrm{D}$ & $\mathrm{E}$ & \\
\hline & & & High & Low & High & Low & \\
\hline \multicolumn{2}{|l|}{ Real CP, \% } & 17.0 & 16.6 & 13.1 & 17.0 & 13.5 & for diets \\
\hline \multirow[t]{2}{*}{ Ammonia, ppm } & LSM & $8.39^{\mathrm{a}}$ & $8.33^{\mathrm{a}}$ & $3.76^{\mathrm{b}}$ & $8.87^{\mathrm{a}}$ & $4.76^{\mathrm{b}}$ & \multirow{2}{*}{$\begin{array}{l}<0.0001 \\
* * *\end{array}$} \\
\hline & $\mathrm{SD}$ & 1.59 & 2.41 & 1.18 & 2.74 & 1.40 & \\
\hline
\end{tabular}

${ }^{\mathrm{a}, \mathrm{b}}$ Values within a row without common letter differ significantly $(P<0.05)$. 
Table 11. Average daily consumption of feeds in different diets A to E, kg of feed or DM.

\begin{tabular}{|c|c|c|c|c|c|c|c|c|c|c|}
\hline & \multicolumn{2}{|c|}{ A } & \multicolumn{2}{|c|}{ B } & \multicolumn{2}{|c|}{$\mathrm{C}$} & \multicolumn{2}{|c|}{ D } & \multicolumn{2}{|c|}{$\mathrm{E}$} \\
\hline & $\begin{array}{l}\text { Feed, } \\
\mathrm{kg}\end{array}$ & $\begin{array}{l}\text { DM, } \\
\text { kg }\end{array}$ & $\begin{array}{l}\text { Feed, } \\
\mathrm{kg}\end{array}$ & $\begin{array}{l}\mathrm{DM} \\
\mathrm{kg}\end{array}$ & $\begin{array}{l}\text { Feed, } \\
\text { kg }\end{array}$ & $\begin{array}{l}\mathrm{DM} \\
\mathrm{kg}\end{array}$ & $\begin{array}{l}\text { Feed, } \\
\mathrm{kg}\end{array}$ & $\begin{array}{l}\text { DM, } \\
\text { kg }\end{array}$ & $\begin{array}{l}\text { Feed, } \\
\mathrm{kg}\end{array}$ & $\begin{array}{l}\mathrm{DM} \text {, } \\
\mathrm{kg}\end{array}$ \\
\hline Hay & 0.99 & 0.84 & 0.98 & 0.84 & 0.99 & 0.84 & 0.98 & 0.83 & 0.99 & 0.84 \\
\hline Silage & 20.8 & 6.19 & 19.83 & 5.87 & 21.88 & 4.96 & 24.23 & 5.76 & 16.56 & 4.89 \\
\hline Beet pulp & 9.73 & 2.56 & 9.48 & 2.50 & 17.17 & 4.52 & 9.24 & 2.43 & 15.53 & 4.08 \\
\hline Grain & 5.57 & 4.86 & 4.90 & 4.25 & 8.16 & 7.12 & 4.06 & 3.54 & 7.59 & 6.58 \\
\hline Control & 6.77 & 5.97 & & & & & & & & \\
\hline SWE 1 & & & 7.43 & 6.62 & 2.50 & 2.19 & & & & \\
\hline SWE 2 & & & & & & & 8.28 & 7.37 & 2.79 & 2.49 \\
\hline
\end{tabular}

gradability (EPD) of beet pulp protein is $61 \%$, resulting in a high supply of AAT (Spörndly, 1995). Sugar beet is a popular plant in the south of Sweden, but cannot be grown in central or northern Sweden (Bertilsson et al., 2001). The economic comparison clearly shows that it is possible to compile diets using products of Swedish origin and still be competitive. On the other hand, the situation may quickly change if world market prices alter. The lower daily feed costs with diets $\mathrm{C}$ and $\mathrm{E}$ may compensate a lower milk production of about $2 \mathrm{~kg}$ of ECM per day.

\section{CONCLUSIONS}

The urea content of milk and contents of total-N and $\mathrm{NH}_{4}-\mathrm{N}$ in manure are strongly linked with the protein content in the diet. The $\mathrm{NH}_{3}$ release from fresh manure can be reduced with lowered protein content in the feed ration. An overfeeding with protein in the diet affects milk quality; hence, more urea is produced. A protein content in the diet around $17 \%$ seems to be sufficient, at least under Swedish conditions. As little as 13 to $13.5 \% \mathrm{CP}$ in the diet seems to be too low, resulting in decreased milk yield. In the south of Sweden, at least, it is possible to have an intensive milk production without any major imports of feedstuffs.

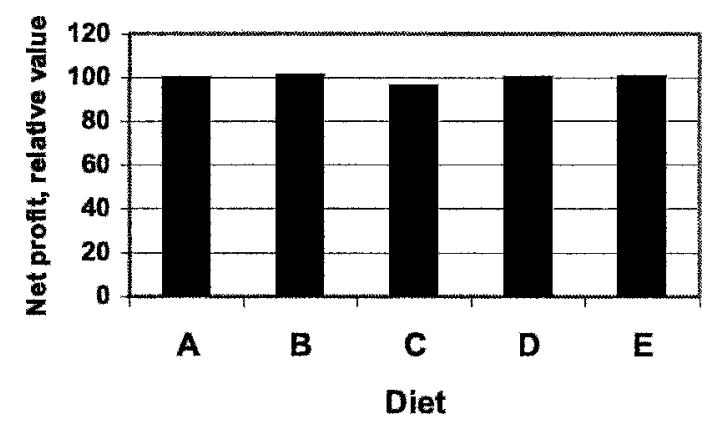

Figure 2. Income over feed costs, relative values.

\section{ACKNOWLEDGMENTS}

Financial support received from the South Swedish Foundation of Agricultural Research is gratefully acknowledged.

\section{REFERENCES}

Aarst, H. F. M., E. E. Biewinga, and H. van Keulen. 1992. Dairy farming systems based on efficient nutrient management. Neth. J. Agric. Sci. 40:285-299.

Andersson, M. 1994. A climate chamber for measuring ammonia emission. Pages 499-506 in Proc. XII World Congress on Agricultural Engineering, Merelbeke, Belgium.

Bertilsson, J., M. Emanuelsson, and M. Salomonsson. 2001. Kan man utfodra korna med enbart närproducerat foder. Svensk Mjölks djurhälso- och utfodringskonferens, Linköping. In Swedish.

Bussink, D. W., and O. Oenema. 1998. Ammonia volatilisation from dairy farming systems in temperate areas. Nutr. Cycl. Agroecosys. 51:19-33.

Chase, L. E. 1999. Animal management strategies-how will they change with environmental regulations. Department of Animal Science, Cornell University. http://www.ansci.cornell.edu/dm/nutrition/nutpub. html 2001-06-18.

Cederberg, C., and B. Mattsson. 2000. Life cycle assessment of milk production-a comparison of conventional and organic farming. J. Clean. Prod. 8:49-60.

Cederberg, C. 2001. Närproducerat foder-bättre för miljön. Svensk Mjölks djurhälso-och utfodringskonferens, Linköping. In Swedish.

Chalupa, W., and J. D. Ferguson. 1996. Impact of nutrition on manure management. Adv. Dairy Technol. 8:301-313.

Dou, Z., R. A. Kohn, J. D. Ferguson, R. C. Boston, and J. D. Newboldt. 1996. Managing nitrogen on dairy farms: An integrated approach. 1. Model description. J. Dairy Sci. 79:2071-2080.

Elzing, A., and G. J. Monteny. 1997. Ammonia emission in a scale model of a dairy cow house. Trans. ASAE 40:713-720.

Frank, B., and M. Nilsson. 1998. Lägre proteintilldelning skonar både miljön och plånboken. SSJ Info nr 11, Alnarp, Sweden. 4 pp. In Swedish.

Gran, K., J. Bertilsson, M. Murphy, B. Everitt, and R. Spörndly. 1993. AAT/PBV systemet som grund för beräkning av enskilda aminosyror till kor. SLU Info rapporter, Husdjur nr 74, Swedish University of Agricultural Sciences. In Swedish.

Godden, S. M., K. D. Lissemore, D. F. Kelton, K. E. Leslie, and J. H. Lumsden. 2001. Relationship between milk urea concentrations and nutritional management, production and economic variables in Ontario dairy herds. J. Dairy Sci. 84:1128-1139.

Gustafsson, A. H. 2000. Miljöeffektiv utfodring av protein till mjölkkor. Svensk Mjölks Djurhälso- och utfodringskonferens, Växjö. In Swedish. 
Hutchings, N. J., S. G. Sommer, J. M. Andersen, and W. A. H. Asman. 2001. A detailed ammonia emission inventory for Denmark. Atmos. Environ. 35:1959-1968.

Jakobsson, C. 1999. Ammonia emissions-current legislation affecting the agriculture sector in Sweden. Regulation of animal production in Europe. KTBL, Arbeitsp. 270:208-213.

James, T., D. Meyer, E. Esparza, E. J. Depeters, and H. Prez-monti. 1999. Effects of dietary nitrogen manipulation on ammonia volatilisation from manure from Holstein heifers. J. Dairy Sci. 82:2430-2439.

Kelly, P. 1983. Sugar beet pulp—a review. Anim. Feed Sci. Technol. 8:1-18.

Klint Jensen, K., and J. Tind Sörensen. 1999. The idea of "ethical accounting" for a livestock farm. J. Agric. Environ. Ethics 2:85-100.

Kohn, R. A., Z. Dou, J. D. Ferguson, and C. Boston. 1997. A sensitivity analysis of nitrogen losses from dairy darms. J. Environ. Manage. 50:417-428.

Kuipers, A., and F. Mandersloot. 1999. Reducing nutrient losses on dairy farms in The Netherlands. Livest. Prod. Sci. 61:139-144.

LRF. 2001. Miljöredovisning för svenskt jordbruk. Lantbrukarnas riksförbund. Stockholm. In Swedish.

Madsen, J. 1985. The basis for proposed Nordic protein evaluation system for ruminants. Acta Agric. Scand. 25:Suppl. 9.

Madsen, J., T. Hvelplund, M. R. Weisbjerg, J. Bertilsson, I. Olsson, R. Spörndly, O. M. Harstad, H. Volden, M. Tuori, T. Varvikko, P. Huhtanen, and B. L. Olafsson. 1995. The AAT/PBV protein evaluation system for ruminants. A revision. Nor. J. Agric. Suppl. 19:1-37.

Magnusson, A-T., J. Bertilsson, B. Everitt, J-E. Lindberg, S. Sanne, and R. Spörndly. 1990. Utvärdering av AAT/PBV-systemet för användning i mjölkproduktionen. Konsulentavdelningens rap- porter, Husdjur nr 68. Swedish University of Agricultural Sciences, Research Information Centre, Uppsala. In Swedish.

Meyer, D., and D. Denise Mullinax. 1999. Livestock nutrient concerns: Regulatory and legislative overview. J. Dairy Sci. 82(Suppl. 2):51-62.

National Research Council. 2001. Nutrient Requirements of Dairy Cattle. 7th rev. ed. National Academy Press, Washington, DC.

Nelson, J. 1999. Managing nutrients across regions of the United States. J. Dairy Sci. 82(Suppl. 2):90-110.

Paul, J. W., N. E. Dinn, T. Kannangara, and L. J. Fisher. 1998. Protein content in dairy cattle diets affects ammonia losses and fertilizer nitrogen value. J. Environ. Qual. 27:528-534.

SAS. 1986. The SAS System for Windows, Release 6.12. SAS Institute, Inc., Cary, NC.

Spörndly, R. 1995. Fodermedelstabell för idisslare. Swedish University of Agricultural Sciences. In Swedish.

St-Pierre, N. R., and C. S. Thraen. 1999. Animal grouping strategies, sources of variation, and economic factors affecting nutrient balance on dairy farms. J. Dairy Sci. 82(Suppl. 2):72-83.

Swiestra, D. J., C. R. Bram, and M. C. Smits. 2001. Grooved floor system for cattle housing: Ammonia emission reduction and good slip resistance. Appl. Eng. Agric. 17:85-90.

The Swedish Government. 2000. Summary of. Gov. Bill 2000/01:130.

Tamminga, S. 1992. Nutrition management of dairy cows as a contribution to pollution control. J. Dairy Sci. 75:345-357.

Tomlinson, A. P., W. J. Powers, H. H. Van Hoorn, R. A. Nordstedt, and C. J. Wilcox. 1996. Dietary protein effects on nitrogen excretion and manure characteristics of lactating cows. Trans. ASAE 39:1441-1448.

Webb, J. 2001. Estimating the potential for ammonia emissions from livestock excreta and manures. Environ. Poll. 111:395-406.

Wu, Z., and D. L. Satter. 2000. Milk production during the complete lactation of dairy cows fed diets containing different amounts of protein. J. Dairy Sci. 83:1042-1051. 